\title{
Tocopherol Transport in the Rat Erythrocyte
}

\author{
R. SILbER, R. Winter, and H. J. KAYdeN \\ From the Department of Medicine, New York University School of Medicine, \\ New York 10016
}

A B S T R A C T The transport of vitamin E ( $\alpha$-tocopherol) has been studied in the rat erythrocyte in vivo and in vitro. Uptake and efflux are independent of energy, but sensitive to temperature. Tocopherol is localized to the cell membrane. Rapid exchange takes place between erythrocytes and serum with an hourly fractional tocopherol efflux of $26 \%$. The vitamin is transferred from the erythrocyte to the low density lipoproteins. These experiments indicate that tocopherol, like cholesterol, is a constituent of the erythrocyte membrane which is in dynamic equilibrium with the corresponding plasma compound.

\section{INTRODUCTION}

Decreased serum levels of vitamin E ( $\alpha$-tocopherol) have been described in premature infants (2) and in hereditary abetalipoproteinemia (3), two conditions associated with a shortened erythrocyte survival. A favorable response to this vitamin has been reported in the anemia of prematurity $(4,5)$. In abetalipoproteinemia the administration of tocopherol restores the increased autohemolysis and peroxide hemolysis toward normal (3). Tocopherol deficiency with abnormal peroxide hemolysis has also been reported in patients with malabsorption (6). While the mechanisms responsible for these effects of $\alpha$-tocopherol on erythrocytes have not been fully elucidated, they may be related to its antioxidant properties. It is not known whether the tocopherol present in plasma or tocopherol adherent to the cell surface is responsible for the protective action. Although the binding of this vitamin to the low-density lipoproteins of normal serum has been well established (7), relatively little is known about its transfer to the red cell. Krishnamurthy and Bieri (8) have reported that after the oral administration of $\alpha$-tocopherol $-{ }^{14} \mathrm{C}$ to the rat, the radioactive vitamin is incorporated into erythro-

This report has appeared in abstract form (1).

Dr. R. Silber is a Career Scientist of the New York City Health Research Council.

Received for publication 5 May 1969. cytes. Kaludin (9) has suggested that in the rabbit, the concentration of tocopherol in erythrocytes is greater than in plasma. The present report describes investigations of tocopherol transport between plasma (or serum) and erythrocytes in the rat. These experiments indicate that $\alpha$-tocopherol is another constituent of the erythrocyte membrane which is in a state of dynamic equilibrium with the plasma environment.

\section{METHODS}

Materials. $\quad \mathrm{D}, \quad l-\alpha$-tocopherol acetate- ${ }^{14} \mathrm{C}(13 \mu \mathrm{c} / \mathrm{mg})$ was generously donated by Hoffman-La Roche. This compound, which was labeled in the number 13 position, was homogeneous in two chromatographic systems (10), and showed the same mobility as carrier $\alpha$-tocopherol. The ${ }^{14} \mathrm{C}$-labeled $\alpha$-tocopherol was fully active biologically when tested in vitamin E-deficient weanling rats. Tocopherol deficiency was induced by feeding vitamin E-deficient diets (Nutritional Biochemicals Corporation). The animals designated deficient had no detectable serum tocopherol.

In most experiments $20-50 \mu \mathrm{c}$ of $\alpha$-tocopherol- ${ }^{14} \mathrm{C}$ dissolved in $0.5 \mathrm{ml}$ of corn oil was administered by gastric tube to normal male Sprague-Dawley or Fisher rats weighing between 150 and $225 \mathrm{~g}$. For in vivo distribution studies, blood from the tail vein was obtained at selected time intervals by drawing blood into heparinized microhematocrit tubes. The tubes were centrifuged for $4 \mathrm{~min}$ in an International microhematocrit centrifuge to determine the volume of packed red cells. The height of the plasma and red cell columns was also measured. The glass tubes were then sliced at the plasma cell interphase and their contents expelled into planchets. The capillaries were thoroughly washed with $2 \mathrm{M} \mathrm{NH}_{4} \mathrm{OH}$ and the washings were added to the planchets. Radioactivity was determined in a low-background gas-flow counter. Correction for self-absorption was not necessary for samples under $40 \mu 1$. The volume of the samples was determined by the formula, $\mathrm{V}=\pi \mathrm{r}^{2} \mathrm{~h}$, where $\mathrm{r}$ is the internal diameter of the capillary and $h$ is the height of the plasma or red cell column. No correction was necessary for plasma trapping.

For in vitro transport studies blood was obtained by cardiac puncture and defibrinated with glass beads. The red cells were separated from plasma and washed three times with $0.15 \mathrm{M} \mathrm{NaCl}$. Mixtures were then prepared containing radioactive serum and nonradioactive red cells or radioactive cells and nonradioactive serum. The hematocrit was adjusted to between 40 and $50 \%$ and $2 \mathrm{mg} / \mathrm{ml}$ of glucose was added. The nonradioactive samples of blood to make these mixtures were sometimes obtained from the same animal before the 
administration of the tocopherol, but in most instances the mixtures were prepared using unlabeled serum and erythrocytes from other animals. No differences were noted in the results obtained with autologous cell-serum mixtures and homologous mixtures. In performing these experiments, no differences were observed in the flux of tocopherol between mixtures shaken at 50 oscillations/min in an Eberbach incubator and mixtures which were not shaken. Therefore, incubations of the mixture were carried out without shaking at $37^{\circ} \mathrm{C}$ unless otherwise specified. Samples were removed at frequent time intervals and processed as described above for the separation of serum from erythrocytes and determination of radioactivity.

Serum tocopherol concentrations were determined by a micromodification of the Emmerie-Engel reaction (11), in which xylene is used for extraction and $\alpha, \alpha$-dipyridyl for color development. Neither this technique nor several others was found satisfactory for the measurement of red cell tocopherol; it was therefore impossible to estimate the concentration of tocopherol in the cells. The fractionation of serum lipoproteins was performed by standard methods (12).

Preliminary to performing exchange studies, it was determined that all of the radioactivity present in the serum and erythrocytes coincided with pure $\alpha$-tocopherol added as carrier in two chromatographic systems. Since defibrinated blood was used and the buffy coat was sacrificed when the red cells were washed, contamination with leukocytes was usually below 2000 cells $/ \mathrm{mm}^{3}$ and the platelet admixture was negligible. In an experiment where graded amounts of buffy suspensions were added to the erythrocytes, no effect was noted on the specific activity of the packed red cells with white cell counts of up to $5000 / \mathrm{mm}^{3}$. All the experiments described in this study were performed at least twice; samples were processed in duplicate.

In the in vitro experiments, tocopherol exchange between the erythrocytes and serum was determined using a modification of the formulae of Wallach, Reizenstein, and Bellavia (13) for exchange between two phases in a closed system. Since the mixture of red cells and serum constitute a closed system, the radioactivity disappearing from one phase must

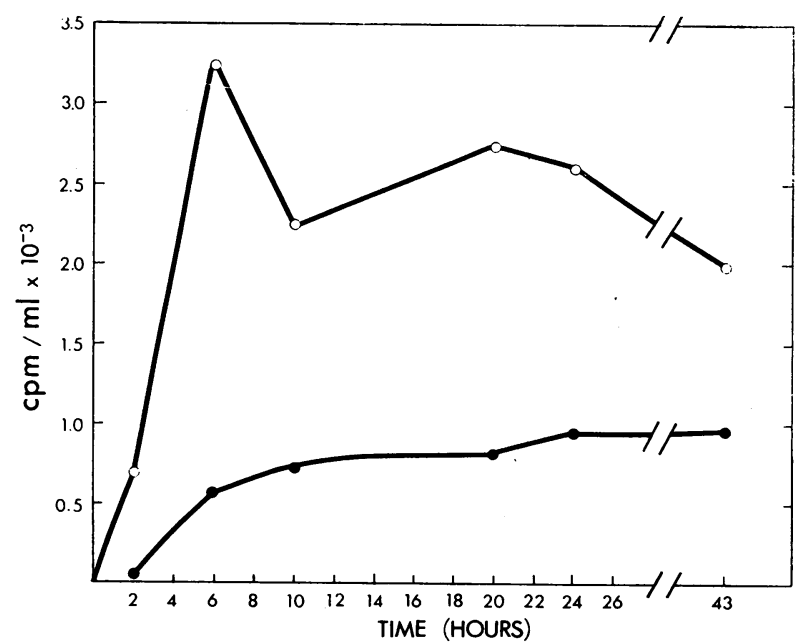

Figure 1 Time course of appearance of tocopherol- $-{ }^{14} \mathrm{C}$ in plasma $(\mathrm{O}-\mathrm{O})$ and erythrocytes (๑) after $20 \mu \mathrm{c}$ were given by gastric tube at $0 \mathrm{hr}$. This pattern is typical of six consecutive experiments.

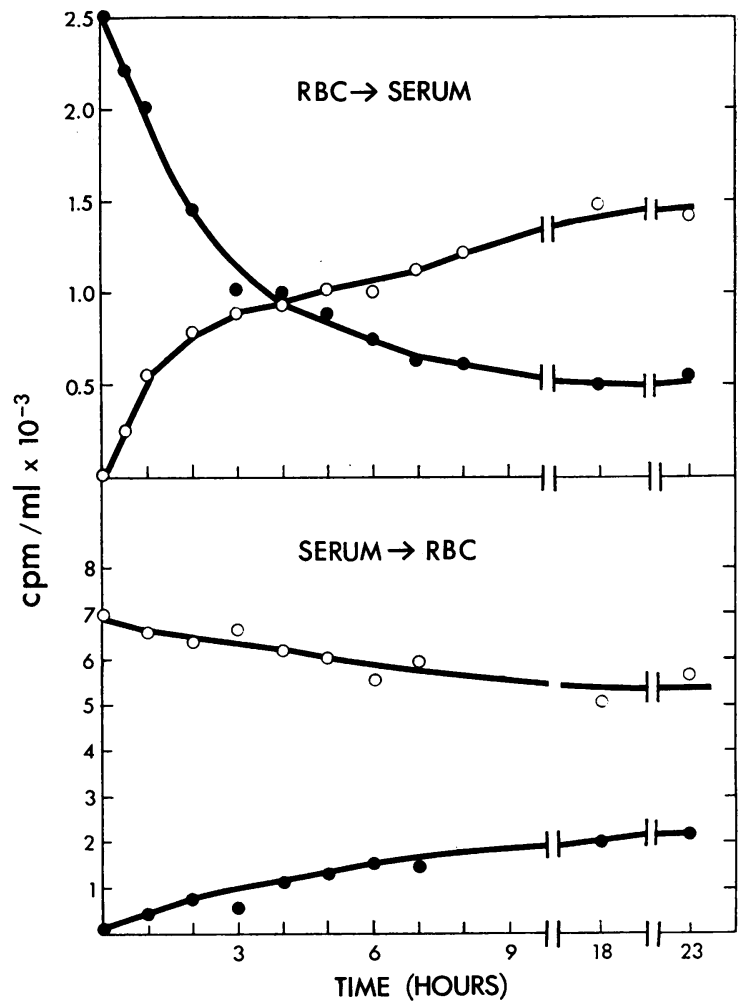

Figure 2 Tocopherol exchange in vitro. Upper: incubation of erythrocytes containing tocopherol- ${ }^{14} \mathrm{C}$ with normal serum. Radioactivity in erythrocytes (-—) and plasma $(\mathrm{O}-\mathrm{O})$ are shown. Lower: incubation of serum containing tocopherol $-{ }^{14} \mathrm{C}$ with normal erythrocytes. Radioactivity in serum $\left(\mathrm{O}_{-}\right)$and erythrocytes (- $)$are shown.

appear in the other. Starting with radioactive erythrocytes, equilibrium between cells and serum was usually reached in about $8 \mathrm{hr}$ of incubation at $37^{\circ} \mathrm{C}$. The concentration of radioactive tocopherol in the serum at equilibrium $(\mathrm{cpm} / \mathrm{ml})$ was designated $S \infty$; while the concentrations before that time are designated $S t\left(t_{1}, t_{2}, t_{3}\right.$, etc. $)$. When the experimental values of $1-\mathrm{St} / \mathrm{S} \infty$ were plotted semilogarithmically against time, a straight line with a slope of $0.693 / \mathrm{t}_{\frac{1}{2}}$ was obtained. The $t_{\frac{1}{2}}$ was determined from the plotted regression line. The flux transfer coefficient from erythrocyte to serum $\left(K_{\mathrm{E} \rightarrow \mathrm{S}}\right)$ was determined by equation 1 :

$$
K_{\mathrm{E} \rightarrow \mathrm{S}}=\frac{\text { slope } \times \mathrm{S} \infty \times \frac{1-\text { Hematocrit }}{\text { Hematocrit }}}{\mathrm{RBC}_{0}}
$$

where $\mathrm{RBC}_{0}$ is the radioactive tocopherol concentration in erythrocytes $(\mathrm{cpm} / \mathrm{ml})$ at zero time.

The system in which serum containing tocopherol $-{ }^{14} \mathrm{C}$ was incubated with unlabeled cells was slower in reaching equilibrium, usually requiring over $12 \mathrm{hr}$, by which time hemolysis was noted in some experiments. Since true equilibrium values could therefore not be obtained with accuracy, the flux transfer coefficient from serum to erythrocyte $K_{\mathrm{S} \rightarrow \mathrm{E}}$ was derived from $K_{\mathrm{E} \rightarrow \mathrm{S}}$ by equation 2 :

$$
K_{\mathrm{S} \rightarrow \mathrm{E}}=\left(\text { slope }-K_{\mathrm{E} \rightarrow \mathrm{s}}\right)\left(\frac{1-\text { Hematocrit }}{\text { Hematocrit }}\right)
$$


The concentration of unlabeled tocopherol in the serum remained constant throughout each study.

\section{RESULTS}

In vivo studies. Fig. 1 shows the plasma and red cell levels of $\alpha$-tocopherol- ${ }^{14} \mathrm{C}$ after intragastric administration of the material in corn oil. Radioactivity is first detectable in plasma at $2 \mathrm{hr}$ (Fig. 1) and reaches a maximum in $6 \mathrm{hr}$ (time of maximum activity in four experiments ranged from 4 to $8 \mathrm{hr}$ ). A decline occurs over the next $4 \mathrm{hr}$, and the activity then remains approximately constant for the remainder of the experiment. In contrast to the sharp peak observed in plasma, the radioactivity rises more slowly in the erythrocyte. A plateau is reached in $10 \mathrm{hr}$.

A typical experiment for determining the rate of transfer of tocopherol- ${ }^{14} \mathrm{C}$ from erythrocytes to serum is shown in Fig. 2. In this experiment, the $T_{\frac{1}{2}}$ of a semilogarithmic plot of $1-\mathrm{St} / \mathrm{S} \infty$ in time was $1.8 \mathrm{hr}$. The reverse experiment, the uptake of radioactivity by red cells, is also shown. The efflux transfer coefficients between erythrocytes and serum observed in five experiments are indicated in Table I. The average flux coefficient for $K_{\mathrm{E} \rightarrow 8}$ is 0.26 and the average flux coefficient for $K_{\mathrm{S} \rightarrow \mathrm{F}}$ is 0.16 . Since the concentration of tocopherol in rat plasma is generally about $1 \mathrm{mg} / 100 \mathrm{ml}$, the calculated average transfer rate from serum to cell is approximately 0.2 $\mathrm{mg} / \mathrm{hr}$ per $100 \mathrm{ml}$. Since the concentration of erythrocyte tocopherol is unknown, the absolute flux from cell to serum cannot be determined with certainty. How-

TABLE I

Bidirectional Tocopherol Transport in Rat Erythrocytes

\begin{tabular}{|c|c|c|c|c|c|c|c|}
\hline Exp. No. : & $t_{3}$ & Slope & $\mathrm{S}_{\infty}{ }^{*}$ & $\mathrm{RBC}_{0} \ddagger$ & Het & $K_{\mathrm{E} \rightarrow \mathrm{S}}$ & $K_{\mathbf{S} \rightarrow \mathbf{E}}$ \\
\hline & $h r$ & & $\begin{array}{c}c p m / \\
\mu l\end{array}$ & $\begin{array}{c}c p m / \\
\mu l\end{array}$ & $\%$ & & \\
\hline 1 & 1.8 & 0.38 & 4.47 & 8.7 & 48 & 0.21 & 0.18 \\
\hline 2 & 1.8 & 0.38 & 2.14 & 3.9 & 44 & 0.26 & 0.15 \\
\hline 3 & 1.7 & 0.41 & 1.5 & 3.5 & 40 & 0.26 & 0.22 \\
\hline 4 & 2.0 & 0.35 & 5.9 & 12.3 & 41 & 0.24 & 0.15 \\
\hline 5 & 1.9 & 0.36 & 1.6 & 4.5 & 40 & 0.28 & 0.10 \\
\hline $\mathrm{AV} \pm \mathrm{SE}$ & & & & & & $0.26 \pm 0.01$ & $0.16 \pm 0.02$ \\
\hline Trypsin§ & 1.8 & 0.40 & 2.6 & 4.6 & 43 & 0.31 & 0.12 \\
\hline Neuraminidase $\|$ & 1.9 & 0.37 & 2.6 & 4.5 & 44 & 0.27 & 0.12 \\
\hline $\begin{array}{l}N \text {-ethylmaleimide } \\
\quad\left(10^{-4} \text { moles } / \text { liter }\right)\end{array}$ & 1.6 & 0.4 & 1.3 & 3.5 & 40 & 0.26 & 0.22 \\
\hline
\end{tabular}

$* \mathrm{~S}_{\infty}$ is the concentration of radioactive tocopherol in the serum at equilibrium.

$¥ \mathrm{RBC}_{0}$ is the radioactive tocopherol concentration at zero time.

\&rythrocytes in $0.15 \mathrm{M} \mathrm{NaCl}$ were incubated with crystalline trypsin $(0.02 \mathrm{mg} / \mathrm{ml})$ for $10 \mathrm{~min}$ at $37^{\circ} \mathrm{C}$. The trypsin was removed by washing the cells three times with 10 volumes $0.15 \mathrm{M} \mathrm{NaCl}$.

$\|$ Erythrocytes in $0.15 \mathrm{M} \mathrm{NaCl}$ were incubated with $\mathrm{V}$. cholera neuraminidase (Worthington) $(0.05 \mathrm{mg} / \mathrm{ml})$ for $15 \mathrm{~min}$. The neuraminidase was removed by washing the cells three times with 10 volumes of $0.15 \mathrm{M} \mathrm{NaCl}$.

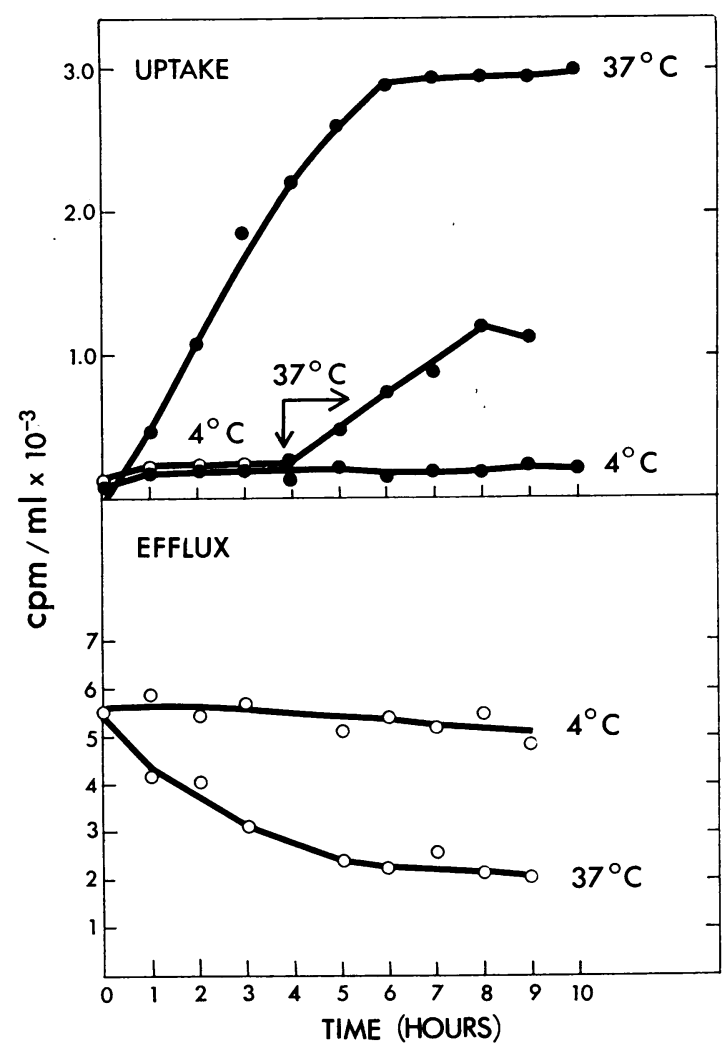

Figure 3 Effect of temperature on the uptake and efflux of tocopherol- ${ }^{14} \mathrm{C}$; upper : incubation of normal erythrocytes with serum containing tocopherol-14 $\mathrm{C}$. Radioactivity in erythrocytes (- ). Lower: incubation of erythrocytes containing tocopherol- ${ }^{14} \mathrm{C}$ with normal serum. Radioactivity in erythrocytes $(\mathrm{O}-\mathrm{O})$.

ever, since the concentration of tocopherol in the serum did not change perceptibly during the experiments, the flux from cell to serum is probably close to the value calculated above.

Effect of temperature on transport. The effect of temperature was determined by incubating aliquots of a cell-serum mixture at $4^{\circ} \mathrm{C}$ and $37^{\circ} \mathrm{C}$. The results of this experiment are seen in Fig. 3 . At $4^{\circ} \mathrm{C}$, the transfer of radioactivity from serum to red cells in this mixture is markedly diminished compared with a companion experiment run at $37^{\circ} \mathrm{C}$. Reversibility of the inhibition of tocopherol exchange by decreased temperature is demonstrated by a resumption of a more rapid transfer when the temperature of the incubation mixture is raised to $37^{\circ} \mathrm{C}$ after $4 \mathrm{hr}$ at $4^{\circ} \mathrm{C}$.

Effect of $p H$ and tocopherol concentration. The flux transfer coefficient of tocopherol moving from erythrocytes to serum $\left(K_{\mathrm{E} \rightarrow \mathrm{S}}\right)$ and the relative amounts of tocopherol- ${ }^{14} \mathrm{C}$ in cells and serum at equilibrium was unaltered over a pH range from 6.0 to 8.0. Hemolysis occurred at higher $\mathrm{pH}$ values. 
The concentration of serum tocopherol and of presumed erythrocyte tocopherol concentration appears to have little influence on the kinetics of tocopherol exchange. The experiment illustrated in Fig. 4 shows that the flux from tocopherol-deficient erythrocytes is similar whether the serum is normal or tocopherol depleted. The flux from tocopherol-depleted serum is similar whether the cells are normal or deficient in tocopherol.

The physiologic basis for these unexpected findings is not clear, but some possible explanations are the following: (a) despite undetectable serum tocopherol levels, the "deficient" cells may still contain some tocopherol and therefore are not truly depleted; $(b)$ the tocopherol content of the administered labeled material may have partly corrected the deficiency and obscured possible differences in flux; $(c)$ the flux transfer coefficients may not be under the control of the tocopherol concentration in serum or cells. More than one of these three effects may have occurred.

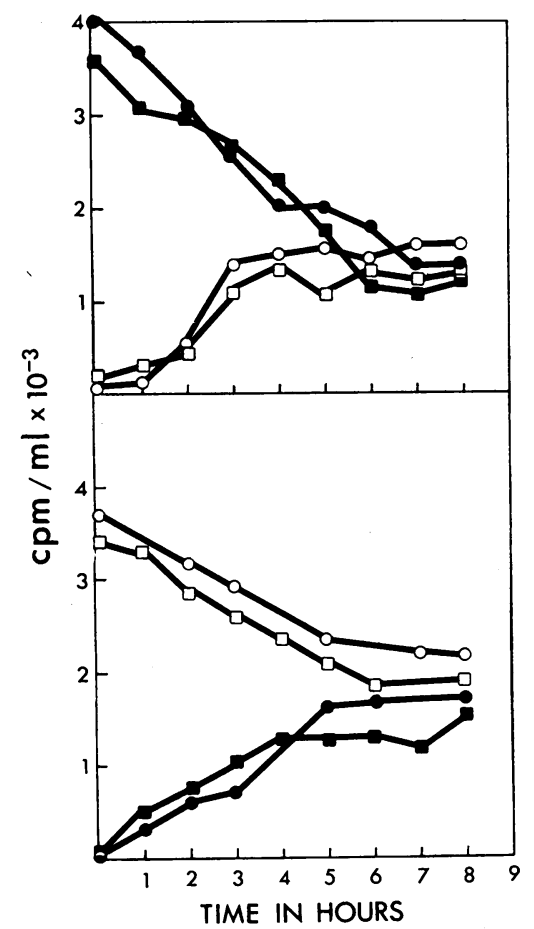

FIGURE 4 Upper: transfer of tocopherol ${ }^{14} \mathrm{C}$ from tocopherol-deficient erythrocytes to normal and tocopheroldeficient serums. Deficient cells $\rightarrow$ normal serum; red cell radioactivity ( $\square-\square)$, serum radioactivity $(\square-\square)$. Deficient cells $\rightarrow$ deficient serum; red cell radioactivity $(\bullet-\bullet)$, serum radioactivity $(\mathrm{O}-\mathrm{O})$. Lower : transfer of tocopherol- ${ }^{14} \mathrm{C}$ from tocopherol-deficient serum to normal and tocopherol-deficient erythrocytes. Deficient serum $\rightarrow$ normal cells; serum radioactivity ( $\square-\square)$, red cell radioactivity ( $\square$ ). Deficient serum $\rightarrow$ deficient cells; serum radioactivity $(\mathrm{O}-\mathrm{O})$, red cell radioactivity $(\bullet-\bullet)$

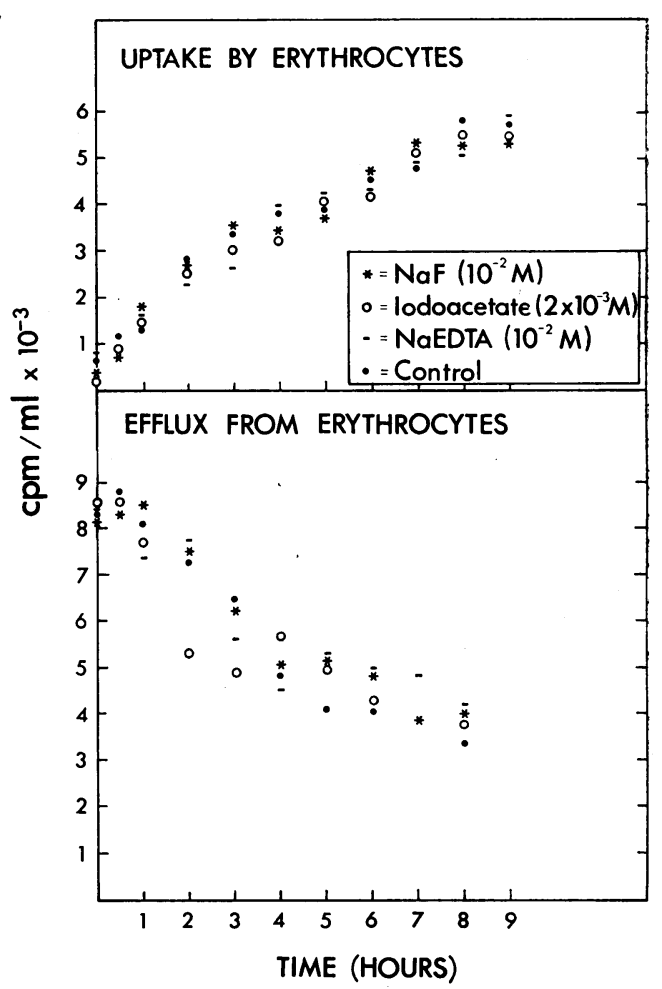

Figure 5 Effect of metabolic inhibitors on tocopherol transport. The compounds shown were added to incubation mixtures with labeled plasma (upper) and to mixtures with labeled erythrocytes (lower).

Effect of inhibitors on exchange. To examine the possible dependence of tocopherol transport on energy production, the effects of two inhibitors of glycolysis were studied. It can be seen that neither iodoacetate nor sodium fluoride in a concentration of $10^{-3} \mathrm{~mole} / \mathrm{liter}$ had a discernible effect on the uptake or release of radioactivity from the red cells (Fig. 5). The addition of $10^{-3} \mathrm{M}$ Na ethylenediaminetetraacetate (EDTA) also had no apparent effect. There was no dependence of tocopherol transport on the cholesterol-esterifying activity of the serum, since pretreating serum for $30 \mathrm{~min}$ at $56^{\circ} \mathrm{C}$ did not affect the flux of tocopherol at $37^{\circ} \mathrm{C}$. Exchange rates were not altered by exposure of the red cell surface to $N$-ethyl maleimide, trypsin, or neuraminidase (Table I).

Serum protein fractionation. To determine whether proteins other than the low density lipoproteins could serve as acceptors for erythrocyte tocopherol, normal rat serum was fractionated by density equilibrium ultracentrifugation in $\mathrm{KBr}$. Low-density lipoproteins floated to the top of the centrifuge tube and were separated from the high-density lipoproteins and albumin which remained in the infranatant solution. After a 16 hr dialysis against $0.15 \mathrm{M} \mathrm{NaCl}$, the fractions were in- 
cubated with labeled erythrocytes. No flux from the erythrocytes could be detected when they were incubated with the fraction containing the high density lipoprotein fraction and albumin (Fig. 6). Transfer to the low density lipoproteins, however, was approximately equal to that observed with control serum which had been stored and dialysed, but not subjected to ultracentrifugation.

Membrane localization. Erythrocytes containing ${ }^{14} \mathrm{C}$ labeled tocopherol were hemolyzed by the method of Danon, Nervo, and Marikovsky (14) in order to prepare ghosts, which after several washes contained less than $1 \%$ of the original hemoglobin. Between 95 and $102 \%$ of the radioactivity originally present in the erythrocyte was recovered in the ghosts (Table II). Within the accuracy of the determinations, it seems not unreasonable to assume that all the radioactive tocopherol is localized in the cell membrane.

\section{DISCUSSION}

The present studies demonstrate that $\alpha$-tocopherol can bind to the rat erythrocyte membrane. $\alpha$-Tocopherol, the main form of vitamin $\mathrm{E}$, contains an aromatic substituted phenol and a long-chain fatty acid. Whereas

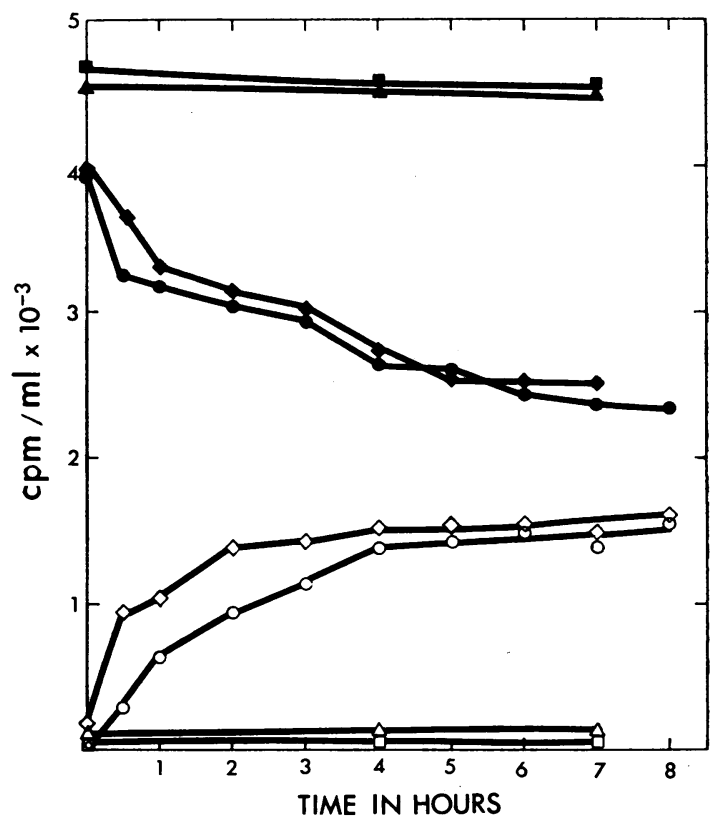

Figure 6 Flux of tocopherol- ${ }^{14} \mathrm{C}$ from erythrocytes during incubation with "whole" serum or serum protein fractions. Erythrocyte radioactivity with albumin ( $\square-\square)$, high density lipoprotein $(\boldsymbol{\Delta}-\mathbf{\Delta})$, low density lipoprotein $(\diamond-\bullet)$, and "whole" serum ( $-\bullet)$. The corresponding values for serum radioactivity are indicated in the lower part of the figure by corresponding open symbols.
TABLE II

Tocopherol Distribution in Rat Erythrocytes

\begin{tabular}{cccc}
\hline & \multirow{2}{*}{$\begin{array}{c}\text { cmp in } \\
\text { erythro- } \\
\text { Eytes }\end{array}$} & \multicolumn{2}{c}{ Recovery } \\
\cline { 3 - 4 } & 780 & Ghost & Soluble \\
\hline \multirow{2}{*}{1} & 780 & 808 & 5 \\
& 780 & 788 & 28 \\
& 324 & 788 & 24 \\
& 324 & 320 & 0 \\
& 324 & 278 & 5 \\
& & 286 & 10 \\
\hline
\end{tabular}

In each experiment tocopherol-14 $\mathrm{C}(100 \mu \mathrm{c})$ was administered by gastric tube. Erythrocytes were collected $24 \mathrm{hr}$ later and washed three times with $0.15 \mathrm{M} \mathrm{NaCl}$. Ghosts were prepared in triplicate as described under methods.

the phenolic group is responsible for the vitamin's reactivity with free radicals, the fatty acid component may account for its solubility in the lipid-rich membrane of the erythrocyte. There is evidence (15) suggesting that cell membranes are formed from repeating lipoprotein units having hydrophobic lipid-protein bonds. It is likely that $\alpha$-tocopherol would have a much greater affinity for the membrane than for the polar aqueous interior of the erythrocytes.

The exchange of tocopherol between erythrocyte membrane and serum occurs at a relatively rapid rate although the data do not rule out the presence of some unexchangeable tocopherol in the red cell. In view of this dynamic equilibrium between erythrocytes and serum, alterations in the tocopherol concentration of serum might affect the amount of tocopherol localized to the red cell membrane during the life span of a given mature erythrocyte. This characteristic of the fat soluble tocopherol stands in contrast to the transport of the water soluble vitamins $B_{12}$ and folic acid. These two vitamins are incorporated into the young red cell and very little exchange with the plasma environment occurs thereafter. Vitamin $B_{13}$ is confined to the interior of the erythrocyte rather than in the cell membrane (16). Unlike the other vitamins, which act primarily on the bone marrow, administered tocopherol will affect the properties of a circulating mature erythrocyte. This concept derives support from clinical studies in tocopherol-deficient patients with abetalipoproteinemia, whose increased autohemolysis is corrected within $24 \mathrm{hr}$ of the administration of tocopherol (3). A rapid correction of the abnormal peroxide hemolysis has also been observed in vitamin E-deficient premature infants given tocopherol (2).

Since the addition of EDTA did not alter tocopherol transport, it appears unlikely that the transport system 
has a critical requirement for divalent cations. Furthermore, dependence on glycolysis seems unlikely in view of its insensitivity to several inhibitors of red cell metabolism. The effects of low temperature and resistance to inhibitors are compatible with a surface-binding reaction. In this respect, the process resembles the first stages of fatty acid incorporation into red cells $(17,18)$ and the exchange of cholesterol between the red cell membrane and plasma which are also independent of red cell metabolism (19). A much slower exchange of erythrocyte lecithin and sphingomyelin with the corresponding plasma phospholipids has been thoroughly documented (20). It appears that tocopherol is transferred to the erythrocyte membrane from binding sites on plasma low density lipoproteins (7). The high density lipoproteins are not involved in in vitro tocopherol transport. The present studies also indicate that albumin, which has binding sites for fatty acids (21), does not serve as an acceptor for tocopherol.

We were unable to detect any alteration of the $\alpha$-tocopherol molecule by the rat erythrocyte during the course of these studies. No evidence for oxidation of the chromane ring or side chain was obtained.

These data may be relevant to clinical situation involving tocopherol, since several recent reports (22-24) indicate that lipid peroxides accumulate in the tocopherol deficient red cell in animals and man. Increased lipid peroxide formation has also been described in cells of patients with paroxysmal nocturnal hemoglobinuria, despite normal tocopherol levels (25). Oxidation of unsaturated fatty acids, particularly arachidonic acid constituent of phospholipids, follows. The loss of phospholipids, an important constituent of the erythrocyte membrane, may then lead to either discrete holes in the membrane, or to a "leaky" membrane with subsequent hemolysis. It appears likely that this mechanism plays a role in the hemolytic anemia of man exposed to hyperbaric oxygen (26) for therapeutic reasons or in the course of space travel. An increased susceptibility to the toxic effect of oxidant drugs may also be present in the tocopherol deficient individual (23).

Preliminary studies suggest that the general features described above for the rat erythrocyte also are found in the erythrocytes of normal man. ${ }^{1}$

\section{ACKNOWLEDGMENTS}

This investigation was supported by U. S. Public Health Service Grants AM-10860 and HE 06481, and a contract from the U. S. Army Research and Development Command. Dr. H. J. Kayden is a recipient of a U. S. Public Health Service Research Career Development Award.

1 Silber, R., and H. J. Kayden. Unpublished observations.

\section{REFERENCES}

1. Silber, R., R. Winter, and H. J. Kayden. 1968. Alpha tocopherol, an exchangeable component of the erythrocyte membrane. J. Clin. Invest. 47: 91a. (Abstr.)

2. Gordon, H. H., H. M. Nitowsky, and M. Cornblath. 1955. Studies of tocopherol deficiency in infants and children. I. Hemolysis of erythrocytes in hydrogen perioxide. Amer. J. Dis. Child. 90: 669.

3. Kayden, H. J., and R. Silber. 1965. The role of vita$\min \mathrm{E}$ deficiency in the abnormal autohemolysis of acanthocytosis. Trans. Amer. Ass. Physicians Philadelphia. 78: 334.

4. Oski, F. A., and L. A. Barness. 1967. Vitamin E. deficiency: previously unrecognized cause of hemolytic anemia in premature infants. J. Pediat. 70: 211.

5. Ritchie, J. H., M. B. Fish, V. McMasters, and $M$. Grossman. 1969. Edema and hemolytic anemia in premature infants. A vitamin $\mathrm{E}$ deficiency syndrome. N. Engl. J. Med. 279: 1185.

6. Binder, H. J., D. C. Herting, V. Hurst, S. C. Finch, and H. M. Spiro. 1965. Tocopherol deficiency in man. $N$. Engl. J. Med. 273: 1289.

7. McCormick, E. C., D. G. Cornwell, and J. B. Brown. 1960. Studies on the distribution of tocopherol in human serum lipoproteins. J. Lipid. Res. 1: 221.

8. Krishnamurthy, S., and J. G. Bieri. 1963. The absorption, storage and metabolism of $\alpha$-tocopherol-C14 in the rat and chicken. J. Lipid. Res. 4: 330.

9. Kaludin, I. 1963. Der Tonopherol gehalt in serum und in Erythrozyten von Kaninchen während der Entblutungsanamie. Int. Z. Vitaminforsch. 33: 443.

10. Bunnell, R. H. 1967. Vitamin E assay by chemical methods. In The Vitamins. P. Gyorgy and W. N. Pearson, editors. Academic Press Inc., New York. 6: 261.

11. Quaife, M. L., N. S. Scrimshaw, and O. H. Lowry. 1949. A micromethod for assay of total tocopherols in blood serum. J. Biol. Chem. 180: 1229.

12. Havel, R. J., H. A. Eder, and J. H. Bragdon. 1955. The distribution and chemical composition of ultracentrifugally separated lipoproteins in human serum. $J$. Clin. Invest. 34: 1345.

13. Wallach, S., D. L. Reizenstein, and J. V. Bellavia. 1966. The cellular transport of calcium in rat liver. J. Gen. Physiol. 49: 743.

14. Danon, D., A. Nervo, and Y. Marikovsky. 1956. Preparation of erythrocyte ghosts by gradual hemolysis in hypotonic solutions. Bull. Res. Council Israel, Sect. E. 6: 36.

15. Korn, E. D. 1966. Structure of biological membranes. Science (Washington). 153: 1491.

16. Retief, F. P., C. W. Gottlieb, and V. Herbert. 1966. Mechanism of vitamin $\mathrm{B}_{12}$ uptake by erythrocytes. $J$. Clin. Invest. 45: 1907.

17. Donabedian, R. K., and A. Karmen. 1967. Fatty acid transport and incorporation into human erythrocytes in vitro. J. Clin. Invest. 46: 1017.

18. Shohet, S. B., D. G. Nathan, and M. L. Karnovsky. 1968. Stages in the incorporation of fatty acids into red blood cells. J. Clin. Invest. 47: 1096.

19. Hagerman, J. S., and R. G. Gould. 1951. The in vitro interchange of cholesterol between plasma and red cells. Proc. Soc. Exp. Biol. Med. 78: 329.

20. Reed, C. F. 1968. Phospholipid exchange between plasma and erythrocytes in man and the dog. J. Clin. Envest. 47: 749.

\section{R. Silber, R. Winter, and H. J. Kayden}


21. Goodman, D. S. 1958. The interaction of human erythrocytes with sodium palmitate. J. Clin. Invest. 37: 1729.

22. Dodge, J. T., G. Cohen, H. J. Kayden, and G. B. Phillips. 1967. Peroxidative hemolysis of red blood cells from patients with abetalipoproteinemia (acanthocytosis). J. Clin. Invest. 46: 357.

23. Jacob, H. J., and S. E. Lux. 1968. Degradation of membrane phospholipids and thiols in peroxide hemolysis. Studies in vitamin E deficiency. Blood. 32: 549.

24. Mengel, C. E., and H. E. Kann, Jr. 1966. Effects of in vivo hyperoxia on erythrocytes. III. In vivo peroxidation of erythrocyte lipid. J. Clin. Invest. 45: 1150.

25. Mengel, C. E., H. E. Kann, Jr., and W. D. Meriwether. 1966. A role of lipid peroxidation in $\mathrm{PNH}$ hemolysis and its relationship to low acetyl cholinesterase (ACHE) activity. Clin. Res. 14: 321. (Abstr.)

26. Mengel, C. E., H. E. Kann, Jr., A. Heyman, and E. Metz. 1965. Effects of in vivo hyperoxia on erythrocytes. II. Hemolysis in a human after exposure to oxygen under high pressure. Blood. 25: 822 . 